\title{
MENGENAL MULTI DIMENSIONAL SCALING
}

\author{
Muhammad Idrus \\ Universitas Islam Indonesia
}

\begin{abstract}
Measurement of psychological attributes is an important aspect in Psychology. Related with that, the application of measurement tools-including tests scaling become important. So far, Most of psychological scales apply uni-dimensional scaling model which is not sufficient to measure double or even multi-dimension of psychological attributes basically. Therefore, it is necessary to apply multidimensional scaling model in psychological measurement.

Multidimensional Scaling (MDS) is a method to represent distance distinction of similarity or unsimiliarity between objects. MDS inferlace with the situations where the stimulus is various with some dimensions simultaneously. Some method's in MDS including: the method of triads, complete methods of triads, the methods of tetrads, the method of multidimension rank-order, the method of multidimensional successive calegories and the method of confusion.
\end{abstract}

Keywords: Multidmensional scaling, uni-dimensional scaling

\section{Pengantar}

Pada awainya ilmu Psikologi menginduk pada filsafat, namun sejak Wilheim Wundt mendirikan laboratorium Psikologi pertama di kota Leipzig pada tahun 1979, Psikologi bersama ilmu-ilmu beberapa ilmu lain yang berkenaan dengan hidup dan kehidupan menyatakan berdiri sendiri. Kelompok ilmu yang memisahkan diri terlebih dahulu diistilahkan sebagai ilmu-ilmu ilmu-ilmu yang lebih muda -termasuk Psikologi- (Suryabrata, 1998).

Pada perkembangan selanjutnya, ilmu-ilmu yang lebih tua mempengaruhi pola perkembangan ilmu-ilmu yang lebih muda, baik secara langsung ataupun tidak langsung. Pengaruh langsung dapat dirasakan dari pengambilan konsep ilmuilmu lebih muda dari konsep ilmu yang lebih tua. Dalam Psikologi pengaruh itu antara lain tampak dari pengambilan istilah seperti perangsang, reaksi, adanya keharusan asumsi distribusi normal dalam populasi untuk pengukuran atribut psikologis, istilah komunitas, dan banyak istilah lain yang merujuk pada ilmu-ilmu yang lebih tua (fisika, biologi, ataupun kimia). Adapun pengaruh tidak langsung dirasakan pada metode- metode yang digunakan oleh limu-ilmu lebih muda yang diambil dari ilmu-ilmu yang lebih tua. Dalam Psikologi pengaruh tersebut tampak darl penggunaan metode observasi, eksperimen, penggunaan rumusrumus statistik dalam anall sis data.

Salah satu aspek penting yang juga mendapat pengaruh kuat dari ilmu-ilmu yang lebih tua adalah pengukuran atribut Psikologi. Disadari bahwa pada dasamya atribut Psikologi tidak memiliki eksistensi riil, melainkan sekadar rekaan teoritis, dan tentu saja tidak mungkin dilakukan pengukuran secara langsung (Suryabrata, 2000). Untuk menyiasatinya Suryabrata $(2000)$ menambahkan bahwa pengukuran hanya dapat dilakukan dengan cara menghadapkan orang pada stimulus yang kemudian akan menimbulkan respon. Dari respon inilah disusun skala, pada sisi inilah psikolog atau para limuwan psikologi telah melakukan proses penyederhanaan.

Terkait dengan hal tersebut penggunaan alat tes -yang di dalamnya menyangkut bagimana penskalaan tesmenjadi satu hal yang sangat penting. Dalam hal penskalaan, Torgerson (1958) mengemukakan tiga (3) pendekatan penskalaan, yaitu metode yang berorientasi 
pada subjek, metode-metode yang berorientasi pada stimulus dan metodemetode yang berorientasi pada respon.

Pendekatan yang berorientasi subjek dilakukan dengan cara individu ditempatkan pada titik-titik tertentu dalam rangkaian kontinum. Tes yang biasa menggunakan pendekatan ini adatah tes prestasi ataupun tes bakat. Pendekatan kedua adalah pendekatan yang yang berorientasi pada stimuius, yaitu menempatkan stimulus pada kontinum atribut psikologis yang bersangkutan. Adapun pendekatan yang berorientasi pada respon adalah meletakkan subjek pada suatu kontinum psikologis berdasarkan kekuatan item yang dipilih atau dijawab dengan benar, sendangkan dalam waktu yang bersamaan aitem-aitemnya diskalakan menurut kekuatan atau banyaknya sifat yang dlmiliki oleh subjek yang memilih atau men jawabdengan benar.

Terkait dengan aktivitas penskalaan ini, Guilford (1954) menengarai bahwa selama ini, diasumsikan bahwa dalam proses penskalaan ni berurusan dengan hanya satu kontinum psikologis saja. Padahal tidak semua penskalaan dapat ditempatkan pada sału rangkaian kontinum. Selaln itu, kontinum Psikologl merupakan sesuatu yang unik dan komplek yang terdiri dari dua dimensi atau lebih. Guilford memisalkan jika menanyakan keputusan afektif pada kontinum menyenangkan-tidak menyenangkan, hasil nilai penskalaan mungkin merepresentasikan variasi atau merupakan satu kontinum gabungan. Secara jelas jika menanyakan tentang keindahan sesuatu, maka sejumlah alasan akan diungkap untuk menyatakan satu benda indah, dan demikian juga tatkala keputusannya benda tersebut dinyatakan tidak indah, maka sederet alasan akan digunakan untukmemperkuatpendapat itu.

Menguatkan hal itu Suryabrata (2000) menyatakan bahwa manakala membicarakan proses pengukuran, maka setidaknya akan terkait pad a tiga hal yaitu (1) subyek, dalam jumlah tertentu; (2) stimulus; dan (3) respon, yang sebenamya memilliki dimensi-dimensi yang berbeda. Dengan begitu sebenarnya tatkala membicarakan atau mendiskusikan tenlang pengukuran, maka senyatanya akan menghadapi hal yang berdimensi 3 (tiga).

Lebih lanjut diungkap oleh Suryabrata (2000) bahwa hal yang berdimensi 3 (tiga) ini oleh para pslkolog kerap direduksi menjadi 2 (dua), bahkan lazimnya mereka melakukannya hanya 1 (satu) dimensi saja. Pada sisi ini bukan saja terjadi simplifikasi, tetapi juga terjadi reduksi. Dalam hal reduksi ini Guilford (1954) menengarainya kerap terjadi pada proses pengukuran slkap. persepsi, belajardan berpikir.

\section{Sekilas Tentang Multidimensional Scaling}

Merujuk pada paparan di atas, dapat dipahami bahwa penggunaan model penskalaan yang berdimensi tunggal (unidimensional) pada dasamya tidak cukup untuk melakukan pengukuran atribut yang memilikl dimensl ganda. Artinya untuk kasuskasus tertentu saja dan yang memilki alasan kuat dapat dilakukan penskalaan model unidimensional, misalnya panjang dan berat (Nunnally, 1981), selebihnya diperlukan model penskalaan yang menggunakan skala multi dimensional (Torgerson, 1958).

Multl dimensional scaling (kerap dlsingkat MDS, dan untuk selanjutnya singkatan ini akan digunakan dalam tulisan Ini) merupakan suatu metode yang mempresentasikan kesamaan atau ketldaksamaan jarak perbedaan antar objek (Suryabrata, 2000). Makin mirip objek tertentu dengan objek lainnya, maka makin dekat jarak antara objek yang bersangkutan, sedangkan makin jauh jarak antar objek menunjukkan makin tidak menyerupal (berbeda).

MDS terkait dengan situasi di mana stimuli secara simultan sangat bervariasi dengan beberapa dimensi (Torgerson, 1958). Sementara Messick (1958a) menyatakan bahwa yang dimaksud MDS adalah satu teknik untuk melakukan estimasi jarak antara titik dari serangkaian stimuli. Pada tulisan lainnya Messick (1955) mengungkap bahwa model pengukuran MDS berdasar pada analisis Euclidean jarak 
psikologis, dan jarak tersebut secara umum dapat diperoleh dari keputusan kesamaan of antara stimuli dibanding dimensi yang telah didefinisikan.

Guilford (1954) menyatakan esensi dari teori MDS adalah sekumpulan stimuli yang sama dapat direpresentasikan sebagai serangkaian titik dalam ruang dimensi $n$. Dalam mengkaji tema yang sama Messick (1955) mengungkap bahwa konsep dasar dari MDS adalah jarak psikologis, yang merupakan konstruk dan secara luas telah digunakan oleh para ahli psikologí, sedangkan keputusan jarak psikologis ini dapat diperoleh melalui konsep kesamaan dan ketldaksamaan di antara stimuli, atau konsep lain dibanding dengan kesamaan (dalam atribut sikap misalnya setuju dan ketidaksetujuan).

Leblh Ianjut Suryabrata (2000) menambahkan bahwa MDS digunakan untuk menellti kesamaan (similarity) dan ketidaksamaan (dissimilarity) satu objek yang direpresentasikan dengan jarak (distance) melalui pengamatan letak titik dalam bidang berdimensi 2 (dua) atau 3 (tiga). Semakin dekat jarak antar titik semakin sama (similarity) atau dapat juga dapat dimaknai semakin tinggi tingkat korelasinya, dan begitu sebaliknya semakin jauh letak titik dari titik lainnya, semakin tidak sama (dissimilarity) atau semakin rendah tingkatkor elasinya.

Dalam tulisannya, Guilford (1954) mengungkap bahwa persoalan kesamaan dan ketidaksamaan muncul pada banyak kasus di ilmu Psikologi. Persoalan tersebut menjadi persoalan dasar pada studi tentang persepsi, belajar dan berpikir. Selain itu, persoalan yang sama juga penting pada pengukuran tentang sikap, apakah dimensi sikap merupakan hal yang spesifik tanpa adanya pengetahuan atau tanpa pengharapan. Banyaknya persoalanpersoalan Itulah yang mendorong penggunaan MDS dalam dunia Psikologi.

Untuk menggambarkan betapa pentingnya pengukuran secara multidimensional, Guilford mencontohkan dengan gambar sebagai berikut.

$D_{1}$

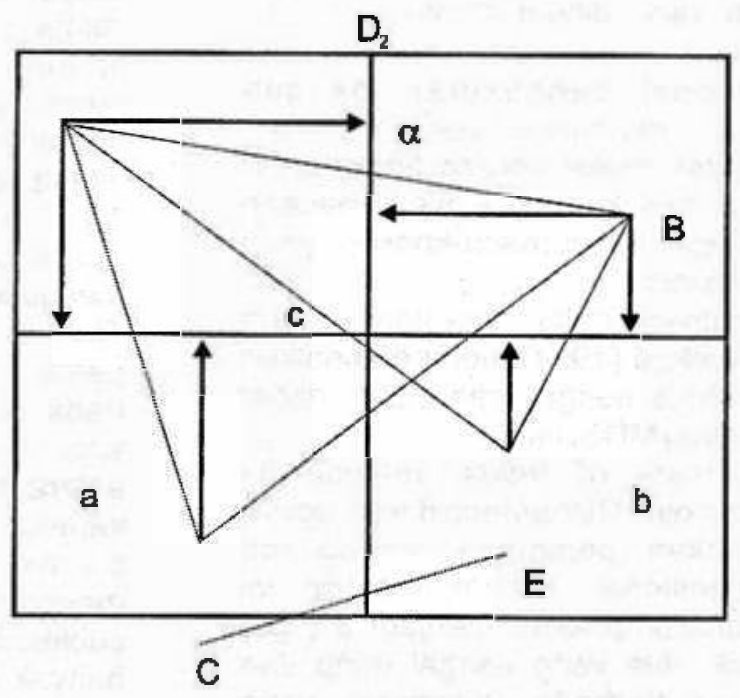

Gambar 1

Contoh $\mathbf{4}$ stimuli direpresentaslkan secara kuantitatif dalam two-dimensional psychological space (dikutip dari Guilford, 1954) 
Pada diagram tersebut ada 2 dimensi variasi dasar $D_{1}$ dan $D_{2}$ yang direpresentasikan bebas. Empat objek A, B, $C, E$ menunjukkan variasi pada dua dimensi tersebut. Jika kita dapat secara baik mendefinisikan dimensi $D_{1}$ dan jika observer dapat memberikan penilaian tentang 4 objek tersebut tanpa terpengaruh dari variasi dalam $\mathrm{D} 2$, maka akan diperoleh skala yang tepat untuk $a, b, c$ dan $\theta$ untuk objek-objek pada dimensi $D$,. Dengan memlsahkan yang direpresentasikan oleh $\mathrm{D}_{2}$, maka terdapat 4 (empat) skala nilai yaitu , , e, pada garis $\mathrm{D}_{z}$ Namun diduga $D_{1}$ dan $D_{2}$ tidak secara jelas diketahui atau observer tidak dapat mengisolasikannya.

Kunci dari hal itu adalah penggunaan jarak Interstimulus $d$ Dengan 4 (empat) objek akan diperoleh" 6 jarak interstimulus. Jarak inilah yang mempresentasikan kesamaan dan ketidaksamaan objek tersebut. Adapun jarak $A B+$ Jarak $B C$ harus sama dengan jarak AC. Jika dengan 3 (tiga) stimuli untuk merepresentasikan jarak interstimuli hanya dibutuhkan dua dimensi saja, sedangkan untuk 4 (empat) stimuli dibutuhkan 3 (tiga) dimensi sebagaimana pada contoh yang dibuat Guiford (1954). Dari gambaran di atas, menunjukkan betapa perlunya model pengukuran dengan menggunakan mutlidimensional scaling. sebab jka tidak maka secara tidak sadar peneliti telah melakukan penyederhanaan bahkan reduksi dari konsep-konsep yang seharusnya muncul.

Selanjutnya dalam bagian tulisan berikutnya Gullford (1954) memperkenalkan beberapa metode pengukuran yang dapat digunakan dakam MDS, yaitu:

1. The methods of triads, metode ini digunakan oleh Richardson dalam upaya memecahkan persoalan pengukuran multidimensional. Dalam metode ini stimuli dikelompokkan menjadi 3 (tiga) kelompok, dua yang sangat mirip dan dua yang berbeda. Informasi yang diperoleh adalah adanya 3 (tiga) penilaian jarak secara rangking dan 3 (tiga) penilaian komparatif terkait dengan jarak tersebut. Ketiga jarak tersebut kemudian mempersoalkan sebagaimana metode perbandingan berpasangan, asumsi bahwa hukum penilaian perbandingan yang diterapkan pada jarak, juga diberlakukan pada stimuli;

2. Complete methods of triads, metode ini direkomendasikan oleh Torgerson. Dalam metode ini setiap tiga serangkai (tiga stimuli menjadi satu, triads) untuk penilaiannya dipresentasikan selama 3 (tiga)kali;

3. The method of tetrads, metode hi juga dijelaskan oleh Torgerson. Intinya secara sederhana metode ini merupakan aplikasi metode perbandingan berpasangan terhadap jarak stimulus. Setiap pasangan stimuli dipasangkan dengan pasangan stimuli lainnya, kemudian dinllal pasangan mana yang memiliki tingkat kesamaan yang lebih tinggl. Hasil dari metode ini adalah perbandingan penilaian dengan asumsi hukum penilalan perbandingan;

4. The mothod of multidimensional rank order, metode ini pernah digunakan oleh Klingberg dalam penelltian eksperimennya. Dalam metode ini setiap stimuli sebagai standar, sisanya $n-1$ stimuli ditempatkan pada urutan rangking dengan memperhatikan tingkat kesamaan terhadap standar yang ditetapkan;

5. The method of multidimensional successive categories, metode ini mengukur jarak antar stimuli;

6. The method of confusion, metode Ini pernah digunakan oleh $F$. Altneave. Pada metode ini subjek diminta untuk secara terpisah mempelajari hubungan antara tanda-tanda objek dan respon kata-kata. kata-kata tersebut sangat berbeda sebagal cara untuk menghindari kebingungan di antara subjek. Satu rangkaian objek terdiri dari banyak segiempat dalam ukuran dan kecerahan tertentu. Rangkaian lainnya terdiri dari segitiga dalam ukuran dan bentuk tertentu. Indikasi tingkat kesamaan Psikologis untuk setiap objek adalah jumlah kekacauan (confusions). 
dimana confusions didefinisikan sebagal satu kata yang diberikan yang dimiliki satu objek dalam merespon terhadap objek lainnya. Skor confusions diperoleh untuk setiap pasangan objek. Meski demikian hasil hasil pengukuran dengan model ini tidak memuaskan, sebab skor untuk jarak hanya 1 dimensi dan tidak sesuai dengan dimensi yang ada;

Rankin (1983) mengungkap tahapan pelaksanaan MDS sebagai berikut:

1. Ada serangkaian $n$ objek;

2. Untuk setiap dua objek ( $i$ dan $j$ ) diperoleh beberapa perhitungan atau fungsi proximity yaitu of (S). Pertitungan tersebut dapat berupa hasil korelasi, kesamaan, hubungan ataupun jarak. Jika diperoloh kesamaan ( $S_{j}$ ) blasanya dikonversi ke jarak teoritik (d) dengan mengurangi konstanta;

3. dipilih sejumlah Jarak ( $t$ ) yang sesuai dengan data, kemudian $n$ objek ditempatkan pada satu ruang dimensional secara acak atau terseleks;;

4. MDS mencari untuk penempatan ulang dari $n$ objek sehingga jarak fislk (d) antara pasangan objek dalam bldang yang berhubungan pengukuran proximity yaitu $f\left(\mathrm{~S}_{\mathrm{i}}\right)=\mathrm{d}_{\mathrm{i}}$ Jika jarak an tar stimuli besar, maka menandakan semakin kecil kesmaannya, sebaliknya jlka jarak antar stimuli kecil, maka menandakan semakin besar tingkat kesamaannya. Selanjutnya jika $d_{l}$ merupakan ukuran jarak, maka hubungannya dengan kesamaan dapat dinyatakan dalam : $d_{1}<d_{q}$ bila $S>S_{k:}$.

Untuk menjelaskan formula pada poin 4, Rankin memberi contoh dengan paangan kata "perang - damai" dengan pasangan kata "perempuan - ibu". Dengan menggunakan formula tersebut, maka formula tersebut dapat menjadi :

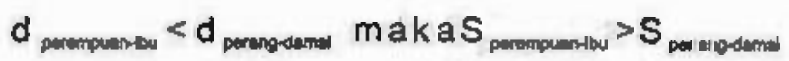

Dari contoh di atas, maka akan tampak betapa jarak pasangan kata perempuan-bu lebih kecil dibanding dengan Jarak pasangan perang-damal, selanjutnya dapat pula diperoleh informasi bahwa kesamaan (similarity) pasangan kata perempuan-ibu lebih besar dari pasangan kata perangdamai.

\section{Perbandlngan MDS dan Analisis Faktor}

Analisis faktormerupakan tehnik untuk menganalisis pola interkorelasi di antara banyak variabel dan memisahkan dimensidimensi untuk menjelaskan pola-pola tersebut, serta untuk memungkinkan simpulan tentang konstruk Psikologi yang direpresentasi dalam dimensi (Isaac dan Michael, 1984). Pendapat yang hampir senada diungkap oleh Gulford (1958) yang menyatakan bahwa analisis faktor adalah metode untuk menganalisis serangkaian hasil observasi tentang korelast untuk menentukan apakah variasi-variasl yang direpresntasikan dapat dijelaskan secara cukup oleh sejumlah katagori dasar yang lebih kecil dibanding apa yang penellt mulai.

Analisis faktor merupakan tehnik untuk menganalls/s pola interkorelasi di antara banyak varlabel dan memisahkan dimensidimensi untuk menjelaskan pola-pola tersebut, serta untuk memungkinkan simpulan tentang konstruk Psikologi yang direpresentasi dalam dimensi (Isaac dan Michael, 1984). Pendapat yang hampir 
senada diungkap oleh Guilford (1958) yang menyatakan bahwa analisis faktor adalah metode untuk menganalisis serangkaian hasil observasi tentang korelasi untuk menentukan apakah variasi-variasi yang direpresntasikan dapat dijelaskan secara cukup oleh sejumlah katagori dasar yang lebih kecil dibanding apa yang peneliti mulai.

Dalam tulisannya Babbie (1973) mengungkap bahwa analisis faktor digunakan untuk menemukan pola di antara variasi-variasi nilai dari beberapa varabel. $\mathrm{Hal}$ tersebut dilakukan melalui hasil dari dimensi artifisial (faktor) yang berhubungan secara kuat dengan beberapa variabel dan yang berdiri sendiri terhadap yang lainnya. Hampir senada dengan ungkapan Babbie, Rankin (1983) menyatakan bahwa analisis faktor adalah usaha untuk menyederhanakan kerangka data dengan mengidentifikasi atau menemukan katagorikatagori dari variabel yang disebut struktur, dimensi atau common factor:

Lebih lanjut diungkap oleh Babbie (1973), hasil dari faktor analisis adalah kolom-kolom yang merepresentasikan beberapa faktor (dimensi artificial) yang dihasilkan dari korelasi data observasi serta korelasi antara setiap variabel dengan faktor yang disebut factor loading, sedangkan has dari analisis faktor bagaimanapun tidak memiliki rujukan terhadap makna variabel, hanya sekadar korelasi empiris. Kriteria yang diperhitungkan adalah: (1) satu faktor harus menjelaskan proporsi besar secara relatif dart varian yang ditemukan: dalam studi, (2) setiap faktor harus independen atau dependen terhadap faktor lainnya.

Rankin (1983) mengungkap bahwa analisis faktor dimulai dari korelasi matrik ( $R$ ) yang diturunkan dari serangkaian respon dari N subjek terhadap sejumlah $\mathrm{K}$ variabel atau stimuli. Seluruh kolom dari data matrik kasar saling berhubungan dengan pasangan-pasangan untuk menghasilkan korelasi matrik. Setiap masukan dari korelasi matrik ( $R$ ) mengukur hubungan antara dua stimuli sebagaimana diterima subjek.

Beberapa kegunaan analisis faktor antara lain (Sumamo, 1995; Fruchter, 1954):
1. Untuk kepentingan eksploratori, yakni eksplorasi dan pendeteksian pola yang ada dibalik data yang teramati (terlihat dari matrix korelasi) dengan harapan dapat menemukan konsep baru atau reduksi data. Meskipun penggunaan eksploratori pada analisis faktor bukan satu-satunya metode, namun penggunaan ini lebih banyak dibanding untuk kepentingan lainnya.

2 Untuk kepentingan konfirmatori, yakni bersifat uji hipotesis tentang struktur ubahan-ubahan yang dikaji, misalnya tentang jumlah faktor dan besaran muatan ubahan pada masing-masing faktor. Penggunaan ini pada akhimya mengembangkan paket-paket program komputerseperti LISREL, COSAN;

3. Untuk kepentingan pengembangan alat ukur, yang ditargetkan pada pembuatan indeks baru yang akan diolah pada tahap berikutnya.

4. Merupakan metode yang efisien untuk menemukan pola-pola yang utama dit antara sejumlah besar variabel; faktor analisis dapat digunakan untuk mengetahui korelasi sederhana, korelasi parsial dan korelasi ganda untuk menemukan pola-polanya;

5. Faktor analisis menamipilkan data dalam bentuk yang dapat diintepretasi oleh pembaca;

6. Analisis faktor menyediakan model matematis yang dapat digunakan untuk memahami sifat area tertentu

Di samping kelebihan yang dimilikinya, kelemahan dari metode analisis faktor tampakdalam hal:

1. Faktor-faktor yang dihasilkan tanpa memiliki makna substantif;

2 Analisis faktor kerap dikritik pada dasar filosofisnya.

Membandingkan MDS dan analisis faktor memang terasa sulit, sebab pada dasarnya baik MDS ataupun analisis faktor memiliki model matematis yang sama (Nunnally, 1981), keduanya juga mengakui adanya dimrensi jamak (Gulfford, 1958), bahkan keduanya merupakan rumpun metode yang digunakan untuk menganalisis serangkaian data multivariat seperti me rating 
atribut jamak untuk sejumlah stimuli (Shifman, Reynold dan Young, 1981). Meskí demikian ada beberapa titik pembeda di antara keduanya antara lain:

1. Analisis faktor ditetapkan untuk skala bagi subjek, sedangkan MDS diterapkan pada stimulus;

2. Data MDS dan analisis faktor samasama dimulai dengan matriks korelasi. Namun dengan menggunakan analisis faktor akan mengalmi kesulitan untuk memahami data tersebut, sedangkan dengan menggunakan MDS pemahaman terhadap data dapat lebih baik karena direpresentaskan dalam dua dimensi;

3. Banyak penggunaan teori analisis butir yang berdasarkan pada teori MDS dibanding analisis faktor;

4. MDS berdasar pada jarak antara titik, sementara analisis faktor berdasar pada sudut antarvektor;

5. Meski keduanya secara umum menggunakan ruang Euclidean, tetapi MDS memperoleh keuntungan dari hal Ini karena secara mudah untuk mengintepretasl jarak antar titik dibanding untuk analisis sudut antar vektor:

6. Dalam pengumpulan data MDS menggunakan penilaian kesamaan secara langsung (direct judgement of similaritjes), sedangkan analisis faktor terkadang memperoleh data yang mungkin tidak berhubungan dengan struktur (Shifman, Reynold dan Young, 1981).

Adapun sujuan penggunaan MDS ini secara umum adalah untuk membantu peneliti melihat struktur data yang diperoleh, sedangkan secara lebih spesifik tujuan tersebutdapat berupa (Rankin, 1983):

1. Sebagai metode yang mempresentasi kesamaan dan ketidaksamaan (similarity dan dissimilarily) data yang berdimensi rendah, sehingga data dapat diperiksa secara visual;

2. Tehnik untuk menguji kriteria yang dlgunakan untuk membedakan berbagai objek secara empiris;
3. Pendekatan analisis data yang memungkinkan orang untukmenemukan dimensi yang mendasari kesamaan atau ketidaksamaan objek, pada sisi Ini MDS memiliki tujuan yang sama seperti analisis faktor;

4. Sebagai model Psikologis yang menerangkan pendapat kesamaan atau ketidaksamaan;

5. Merepresentasikan informasi yang ada dalam matrik korelasl

Melihat keleblhan-kelebihan yang dimiliki MDS, pada akhirnya Shifman dkk. (1981) menyimpulkan bahwa MDS memiliki makna yang leblh baik, serta merupakan metode pemecahan masalah yang secara mudah dintepretas| dibandingkan analisis faktor.

\section{Hal-hal yang Perlu Diperhatikan Dalarn MDS}

Nunnally (1981) mendeskripsikan beberapa hal yang biasanya dilakukan dalam MDS yaitu, (1) dalam MDS subjek tidak diperintahkan untuk membuat respon terhadap dimensi tertentu, blasanya mereka diminta untuk merespon hanya dalam kontek kesamaan dan perbedaan di antara stimuli, misainya memutuskan apakah stimulus a lebih menyerupai $b$ dibanding dengan $c_{1}$ (2) dalam MDS peneliti lebih memperhatikan keputusan dibanding pendapat (perasaan), sehingga meski peneliti mengetahui unsur fisik utama yang membedakan stimuli, hal ini tidak pasti bagaimana dimensi tertentu secara nyata termasuk dalam proses psikologis yang mendasari keputusan.

Perbandingan jarak yang diperoleh metode MDS analog dengan skala unidimensional dalam hal perolehan stimulus-objek dalam metode jenis perbandingan pasangan tradisional (Torgerson, 1952). Pada metode unidimensional, skala perolehan menempatkan stimulus-objek dengan memperhatikan yang lain dalam kontinum yang diberikan. Torgerson (1952) memberi contoh untuk 4 (empat) stimulus-objek $S_{1}, S_{2}$, 
$S_{3}$ dan $S_{4}$, pada prosedur unidimensional mungkin akan memberikan skala sebagai berikut.

\begin{tabular}{llll}
\hline$S_{1}$ & $S_{2}$ & $S_{3}$ & $S_{4}$
\end{tabular}

Pada skala ini, lokasi stimuli satu dan yang lainnya secara relatif ditentukan dari data. Titik nol dalam skala tersebut berubah-ubah. Bila prosedur umum untuk menempatkan titik nol berhubungan dengan stimulus yang memiliki skala nilai terendah, akan sangat membantu lokasi titik lain yang dapat dihitung pada kontinum.
Pada skala multidimensional, pengganti stimulus-objek adalah jarak antara dua stimuli secara berpasangan. Dengan 4 (empat) objek sebagaimana pada contoh unidimensional, maka akan diperoleh 6 jarak antar-stimulus, yaitu $d_{12,} d_{13}, d_{16}, d_{29}, d_{24}, d_{34}$., sehingga jika dibuat dalam garis mungkin akan berupa sebagai berikut.

\begin{tabular}{llllll}
\hline$d_{3}$ & $d_{12}$ & $d_{23}$ & $d_{24}$ & $d_{13}$ & $d_{14}$
\end{tabular}

Meski demikian, Torgerson menambahkan bahwa lokasi jarak inter-stimulus masih relatif terhadap lainnya dan tetap ditentukan dari data. Titik nol juga masih ditentukan secara berubah, dan perbandingan jarak bukanlah jarak dalam konteks senyatanya, tetapi merupakan jarak minus suatu konstanta yang tidak diketahui. Untuk mendapatkan jarak absolut antara stimulus dilakukan estimasi konstanta. Dengan begitu perbandingan jarak $h_{\text {i }}$ ditambah konstanta yang tidak diketahui (C) akan menghasilkan jarak absolut $d_{\text {w. }}$ Dalam mengestimasi penambahan konstanta diasumsikan bahwa nllai yang dimungkinkan stimulus untuk dicocokkan secara nyata dalam ruang euclidean dari dimensi terkecil yang mungkin adalah nllal yang diinginkan.

Untuk menjelaskan hal ini, Torgerson (1952) memberi contoh dengan 5 (lima) titik yang memiliki perbandingan jarak $h_{1}(j, k=1,2, \ldots 5 ; j k$ ), sehingga diperoleh harga sebagai berikut:

$$
\begin{array}{lllll}
h_{12}=1 & h_{14}=1 & h_{23}=1 & h_{25}=0 & h_{35}=-1 \\
h_{13}=2 & h_{55}=-1 & h_{24}=4 & h_{34}=1 & h_{45}=0
\end{array}
$$


Dari perbandingan jarak nilai dari penambahan konstanta yang dimungkinkan untuk dicocokkan dengan stimuli secara real dalam ruang euclidean adalah 4 (empat), dan jika angka 4 (empat) ini ditambahkan untuk setiap perbandingan jarak maka akan diperoleh jarak absolut yaitu:

$$
\begin{array}{lllll}
d_{12}=5 & d_{14}=5 & d_{23}=5 & d_{25}=4 & d_{35}=3 \\
d_{13}=6 & d_{15}=3 & d_{24}=8 & d_{34}=5 & d_{45}=4
\end{array}
$$

Kelima stimuil tersebut dapat ditempatkan dalam ruang dua dimensional sebagai berikut.

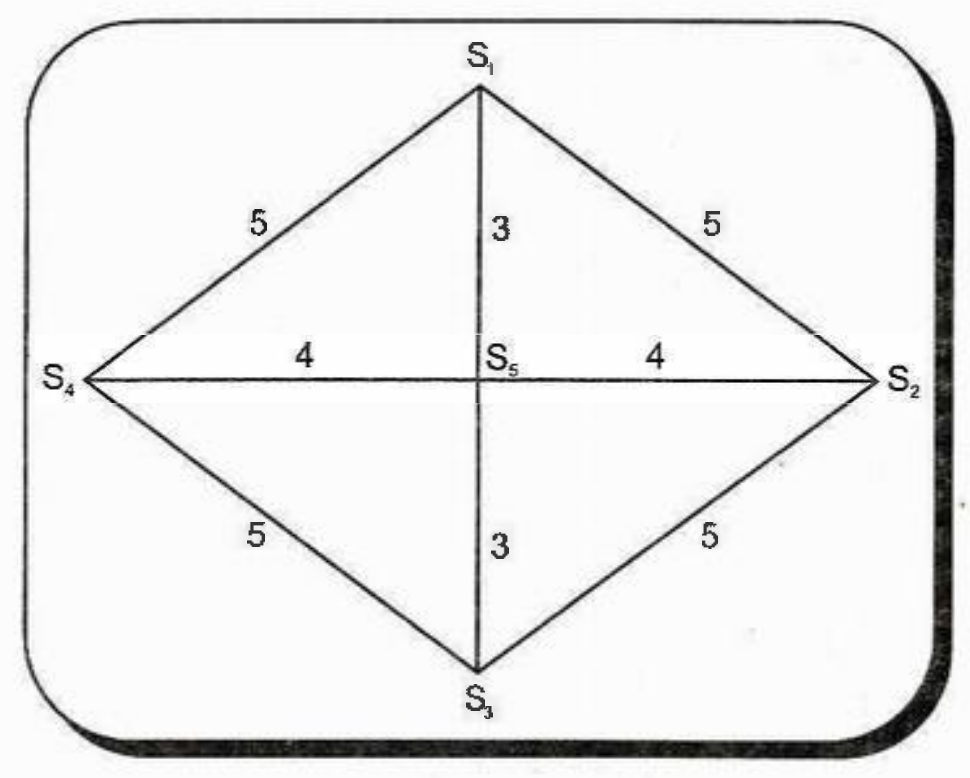

Ganbar 2.

Ruang dua dimensi

(dikutip dari Torgerson, 1952) 
Harus dipahami bahwa penambahan angka yang lebih tinggi ataupun yang lebih rendah dari yang seharusnya tidak memungkinkan terjadinya ruang euclidean, sebagai misal penambahan 1,2 atau 3, maka yang akan terjadi adalah $d_{45}+d_{25}<d_{24}$. Dalam model Euclidean jarak antar stimuli diformulasikan dengan rumus:

$$
d_{j k}=\left[\sum_{m=1}^{1}\left(a_{m m}-a_{k m}\right)^{2}\right]^{1 / 2} \quad(i, k=1,2, \ldots n)
$$

Rumus ini merupakan aplikasi dari teori Phytagoras (Torgerson, 1958).

Dari formula tersebutjarak antara titikj dank digambarkan sebagai berikut:

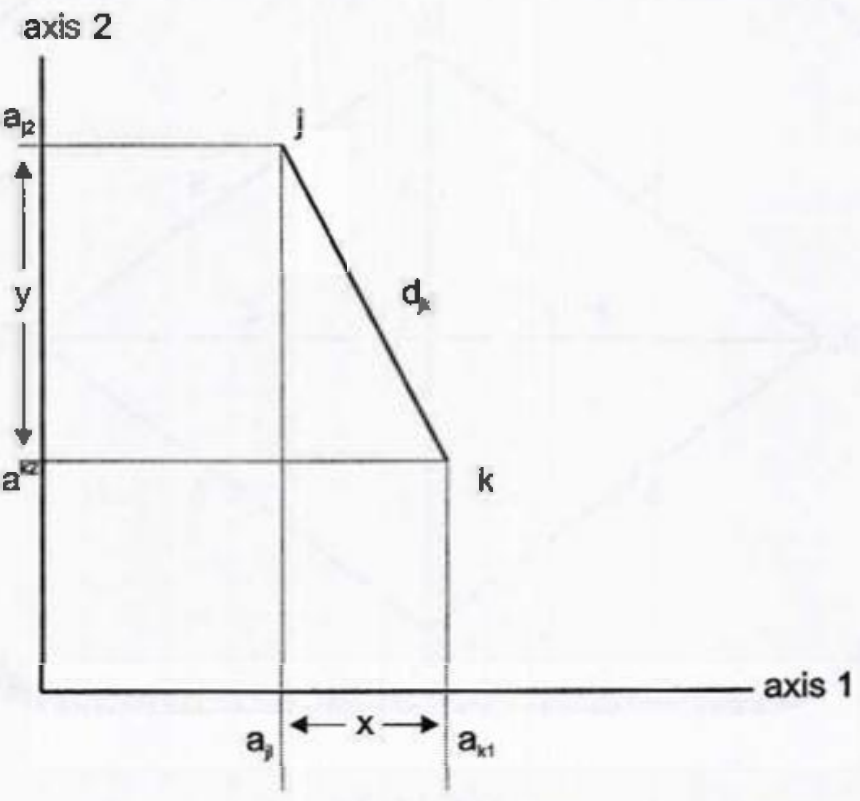

\section{Gambar 3}

Ruang Eucledian

(Torgerson, 1958) 
Dalamr ruang euclidean perbandingan jarak antar titik adalah tetap.

Aplikasi konsep di atas dibaratkan jika seseorang duduk pada saku kursi di tengah ruang, sebenarnya yang bersangkutan tidak terpisah dari sudut-sudut lain. Pada dasarnya yang bersangkutan berada pada tiga-demensi ruang eucledian, baik dihitung dari lantai, atap ataupun tembok. Jika orang tersebut dinotasikan dengan satu titik, maka di sekitar dirinya banyak titik-titik yang merepresentasikan sesuatu yang ada dalamt ruang tersebut.

Dalam bidang unidimensional akan sulit untuk menjelaskan makna dari sekian titik yang saling berdekatan ataupun berjauhan. Situasi di atas dapat digambarkan dalam multidimensi, dan menempatkan titiktitik tersebut berdasar kedudukan senyatanya, misalnya dilihat dari titik orang yang sedang duduk. Dari gambaran tersebut dapat diketahui ada titik (misalnya titik c) yang letaknya dekat dengan titik yang merepresentasikan orang yang sedang duduk (sebutlah sebagai titik a), namun ada juga titik yang letaknya begitujauh dari titik a, katakanlah titik tersebut titik d.

Dengan menggunakan model satu dimensi, jauhnya titik a dan d tidak dapat terlihat secara baik, sedangkan dalam model MDS penampakan tersebut akan lebih jelas lagi. Jauhnya posisi titik d dari titik a secara tidak langsung merepresentasikan jauhnya korelasi atau tidak adanya kesamaan antara titik a dengan titik d sebaliknya semakin dekat letak satu titik dengan titik $a_{\text {r }}$ secara langsung mengisyaralkan adanya korelasi yang tinggi atau adanya kesamaan di antara keduanya. Dalam hal ini kelebihan MDS dibanding analisis sejenisnya (analisis faktor) adalah kemampuannya untuk menyajikan hasil analisis dalam bentuk struktur yang dibantu akses visual dan teramati. Secara ringkas metode MDS akan menjelaskan dimensi-dimensi yang mendasari satu atribut tertentu (analisis eksploratoris bentuk tak tentu; eksploratoris untuk uji hipotesis; eksploratoris ternadap struktur psikologis), dan untuk keperluan konfirmatori (Suryabrata, 2000).

Semakln canggihnya perangkat lunak komputer memudahkan program MDS dioperasionalkan. Beberapa program komputer yang menyediakan fasilitas untuk perhitungan MDS adalah MINISSA, POLYCON, KYST, INDSCAL/SINDSCAL, ALSCAL, MULTISCALE (Shifman dkk , 1981).

\section{Dukungan MDS Bagi Penelitian}

Sebagaimana diungkap dalam pengantar tulisan ini, bahwa proses pengukuran merupakan salah satu unsur terpenting dalam bidang Psikologi, terlebih bagi mereka yang menggeluti bidang psikometri. Selain itu pada dasarnya seluruh proses penelitian yang menggunakan desain kuantitatif dan menggunakan atribut Psikologi sebagai bidang kajiannya akan dengan sendirinya berusaha mengungkap fenomena tersebut melalui instrumen (skala, angket, self report). Meski demikian, kerap terjadi peneliti melupakan bahwa fenomena yang diturunkan dalam instrumen (skala) hanyalah model reduksi dan simplifikasi dari fenomena yang senyatanya, sebab kerap diabaikannya dimensi-dimensì lain.

Mengenal MDS rasanya mendapat satu pencerahan tentang bagalmana seharusnya membuat Instrumen (skala) yang sesuai dengan yang seharusnya. Sebab dari instrumen (skala) itulah data yang akan dianalisis dapat diperoleh. Bukan hanya itu, dengan MDS stimuli yang direspon oleh para responden dapat diketahul keeratan antar faktor yang ada di dalamnya. Jika analisis faktor mampu mengelompokkan butir-butir soal dalam faktor sesual dengan jawaban yang dibuat responden, maka MDS memiliki kemampuan lebih dari itu, yaitu menampakkan keeratan hubungan antar butir yang mernpresentasikan kesamaan satu butir dengan butir lainnya.

Selain dari itu, MDS juga secara langsung dapat menampakkan analisis yang seharusnya dilakukan secara terplsah. Misainya mengambil contoh dari hasil penelitian Endler dan Parker (1990), dari konstruk instrumen (skala) yang dirancang memiliki tiga faktor yaitu task emotion dan avoidance. Seandainya peneliti ingin meneliti 
ada tidaknya perbedaan laki-laki dan perempuan dalam emosi terkait dengan penusatan perhatian, maka peneliti tidak perlu lagi melakukan analisis varian sebagaimana diharuskan dalarn statistik. Dari korelasi yang diperoleh peneliti dapat secara langsung melihat ada tidaknya perbedaan (similarity \& dissimilarity).

Seharusnyalah mereka yang melakukan penelitian dengan mengambil objek kajian atribut psikologi harus menggunakan model MDS. Rekomendasi ini sebenarnya tidak terbatas hanya pada mereka yang menempuh pendidikan di psikologi saja, sebab pada banyak penelitian atribut psikologi kerap dijadikan tema kajian dalam penelitian meski asal peneliti bukan dari fakultas psikologi, atau orang yang menempuh pendidikan di Psikologl.

\section{DAFTAR PUSTAKA}

Babbie, E. R 1973. Survey Research Methods. Belmont: Wadsworth Publishing Company, Inc.

Endler, N.S \& Parker, J.D.A. 1990. Mulltidimensional Assessment of Coping: A Critical Evaluation. Joumal of Personality and Social Psychology (58) 5: 844-854.

Fruchter, B. 1954. Introduction to Factor Analysis. New York: D. Van Nostrand Company, Inc.

Guilford, J.P. 1954. Psychometric Methods. New York: McGraw-Hill.

Isaac, S. \& Michael, W., B. 1984. Handbook in Reseach and Evaluation. San Diego: EdITS Publisher.

Messick, S. J. 1955. Some Recent Theoritical Developments in Multidimensional Scaling. Psychometrika. (16) No. 1: 82-99.
1956. An Empirical Evaluation of Multidimensional Scaling. Psychometrika. (21) No. 4:367-375.

1956. The Additive Constant Problem in Multidimensional Scaling. Psychometrika. (21) No. 1: 1-15.

Nunnally, J.C. 1981. Psychometric Theory. New Delhi: Tata McGraw-Hill Publishing company Limited.

Rankin, PD. 1983. Scalling Methods. New Jersey: Lawrence Erlbaum Associates Publishers.

Schifman, S.S, Reynolds, M.L, \& Young, FW. 1981. Introduction to Multidimensional Scaling. Now York Acadernic Press.

Sumarno. 1996. Analisis Faktor: Penerapannya dalam SPSS. Materi Perkuliahan Metode Pengukuran di PPS IKIP Yogyakarta.

Suryabrata, S. 1998. Pengembangan Alat Ukur Psikologis. Jakarta: Ditjen Dikti Depdikbud RI.

2000. Multi Dimensional Seallng. Diktat Kullah pada Program Doktor Psikologi UGM. Tidak Diterbitkan. Yogyakarta: Program Studi Psikologi Sekolah Pascasariana UGM.

Torgerson, W. S. 1952. Multidimenslonal Scaling: I. Theory and Method. Psychometrika. (17) No. 4: 401419.

1956. Theory and Method. of Scalling. New York: John Wiley \& Son., Chap 11, Pp. 247-297. 